\title{
Paradigm of Light in Lucian Blaga's Outlook: A Semiotic Approach
}

\author{
Coculiana Acăr \\ Faculty of Philosophy and Socio-Political Sciences, University of Iași, Romania
}

Copyright $\mathrm{C} 2019$ by authors, all rights reserved. Authors agree that this article remains permanently open access under the terms of the Creative Commons Attribution License 4.0 International License

\begin{abstract}
In the Blagian philosophic and literary creation there are a multivalent perspectives of light, symbolically connected to: the ontological / physical significance of the light-sign, cosmologically assumed; the gnoseological function ("minus" and "plus knowledge" / enlightment, respectively paradisiac-logical and luciferic-poetic cognition); the (pr)axiological / psycho-emotional perspective, where the "erotic-love" significance prevails through the empirical symbolism of burning. Connecting all these symbolic hypostases, the (Complex) Light passes through a double metamorphic circuit, namely: God (Great Anonimus) / Sacred Light cosmos / physic light - human / bio-phycho-light super-human / noesic light - God. In terms of Blaga, the terrestrial horizon is no longer the limit where physical visibility ceases, but the whole complexity where the metaphysical / spiritual vision extends, because, for the philosopher-poet, the world is not only a cognoscible reality in its immediate realm, but also a world of signs, of symbols that reveal the original faces of the universe. In synthesis, the paper tries to configure a transdisciplinary vision of the whole Blagian creation, having as its "core nucleus" the semiotic paradigm of LIGHT-SIGN, for which the Poems of the Light are standing as a defining measure.
\end{abstract}

Keywords Light, Ontos \& Logos, Magic, Eros \& Thanatos, Knowledge \& Living

\section{Introduction}

In the context of the paper, I have chosen - from the multitude of its concepts - to use the concept of paradigm in Plato's meaning which refers, on the one hand, to the world of ideas, the prototype of the sensitive world in which we live, and, on the other hand, to a principle which distinguishes the fundamental ties and oppositions between notions specific to the thinking; in an exemplary case, model, prototype, ideal situation. Or, by synthesizing, we shall say that the "paradigm of light" defines the preamble of a unifying theory between physics and metaphysics, a unification of which the present time has an essential need. And which Lucian Blaga guessed it brilliantly.

The light is the fundamental premise of the world's genesis, the primordial element generating the cosmic energy and information, and also the human energy. There is, in Blaga's creation, a polyvalence of light, whose "functions" we intend to detail. One is the cosmogonic significance of light in a demiurgical sense, another is the ontological meaning in the sense of cosmo-ontology dominated by the insurmountable mystery and another is the gnoseological function (light "minus-knowledge") in the sense of agnostic gnosis - called by Blaga "the angular stone system of my epistemological system", as it appears from the lyrics "but I, / I with my light increase the mystery of the world." As to the erotic meaning, it refers to the empirical symbolism, burning and consuming, but also to the "gray" metaphor with the meaning of a plenary process of purification.

In this direction, we intend to emphasize that in approaching Blaga's work, two inclusive concepts combine: the light and the sign, namely the ontos - the (meta) physical reality - and the logos, which signify the conceptual approach, the procedural reason by which the sign manifests itself. Starting from the ontological significance, in the sense of cosmo-ontology dominated by the insurmountable mystery, in the Blagian creation one can observe that the (meta) physical horizons of light lie at the interference between mystery and revelation, with the role of putting the human existence in the horizon of the mystery. Thus, the symbol of the light, as an absolute emblem of a universe refusing the direct reception, becomes emblematic for the artist's entire creative existence. From the Oriental art and thinking, he takes the direct aspiration to absolute, transfiguring the transcendent horizon into the expression of deepening in its interior infinite, of dissolution in the light. The idea of mystery has an important role in the ontological construction of the world. 


\section{Hypostases of Blag's Light in the Semiotic Analysis Horizon}

\subsection{The Cosmogonic Meaning of the Light}

Without an approach to the genesis of the world, the cosmological and ontological problem cannot be approached, and without this, the human and his condition cannot be explained, an axiological reference cannot be found for the foundation of an existential judgment. The primordial cosmic light is the explosive light created on the $1^{\text {st }}$ Day, which signifies an "ordering of chaos by vibration, so by light" [1]. The secondary cosmic light is the quality of the matter to be "light frozen in the whirlwind of corpuscular waves" [2] which justifies both the genesis of cosmic bodies (galaxies, stars) and the role of light in the manifestation of forms, of the cosmic electromagnetic radiation (infrared, visible, ultraviolet). In this sense, "cosmology shows that light is the vehicle through which humans can know the Universe (...) each photon emitted by an atom contains information about the processes that have taken place in their emission" [3].

In the Cosmological Trilogy, starting with the Great Anonymous, which the philosopher places, as a generator of substantial and structural maximum complexity, in the metaphysical centre of the Universe, the author notes that the genesis of this Universe would first go through a precosmic phase, then a phase of the direct generation (release of divine, heterogeneous and homogenous differentiation), and finally of a phase of the indirect genesis (of cosmic integration of the divine differentiation). For Blaga, the Great Anonymous is not beyond mystery, but occupies the central place in the world of mysteries. The penetration of the human into the mystery universe involves a vertical cognitive approach that opens the perspective of the transcendent, which is, however censored. Establishing the transcendent censorship, the Great Anonymity defends its heterogeneous status, and the human condition only serves the purpose of living under the sign of the mystery and revealing it. From this assignment, the author develops an original view of the sand glass Universe, parallel to the "tear Universe" [4].

Present in many other cultures (Asian and Arabic, but also European), the sand glass imagology comes to explain that "there is communication between the two cups" [5]. In other words, through the girdle (orifice) of the sand glass "the communication is possible in both directions". The void and the full must follow each other, the immanent and the transcendent being always in a correspondence of substantial energy. By setting up the divine differentials, Blaga, the thinker "imagined a specific sand glass Universe" where the crossing gate is the transcendent censorship. In the upper cup the Great Anonymous would be sat (from Philosophy) and the Devil (in Dramaturgy), and in the lower world the censored human world, which remains the nostalgia of revelation and the continuation of the mystery horizon. In the hourglass Universe thought by Blaga, the communication "is only possible in one direction", from the Great Anonymous to human. The transcendental censorship that has been set up means that, reversely, the communication is no longer possible, hence, the absolute hypostasis of the differential generator withdrawn into a sufficient almighty to itself, a self-exiled demiur from his own creation.

Returning to creation, the contouring of the sand glass-space was due to the transition from implosion to explosion carried out according to laws applied to the evolution of the cosmic matter in the space of the galactic ellipsoid. A continual transformation of the "explosion" into "implosion" [6] and vice versa, in an endless construction of contradictions: light - dark - light. Thus, the quality of the "unifying paradigm" of light refers to the isomorphism between human, atom and galactom, between the physical, biological, and psycho-social matter. At the interference between the physical structure of the world's systems (shaped from substance and energy, information and field) and their metaphysical function are the essential forms of the world: the ovoid, the column and the cluster. These forms - present in all the hierarchical systems of the world, are the result of the field effects (including electromagnetic), having as an ordering process the resonance. This process also explains the genesis by the constant light of the human intuition". [7]

\subsection{Morphological Extensions of the Light}

The light has a cosmic circuit in the sense that it opens the look of the image of the natural forms within which there are in a latent status, the ideal forms that will be received by the intellect. So, starting from the level of the physical light, we define in the space of metamorphosis three ways of being of the light: bio light (bioluminescence), specific to the biological stage of living, generally, of the human one, in particular; pycho light (psycho luminescence), characteristic to the psychic activity (affective-emotional), of the human being; noesi light characterizing the emission of "spiritual light" generated by the mental activities (volitional-intellectual) of the human being. At the intersection of these horizons the "complex light" is defined [7, p.250]. Cosmogony "serves as an archetypal model for all creations in any plan it is developed: Biological, Psychological, Spiritual" as it "provides the model"[8].

The metamorphoses of the light spent in the processuality of the creative development are defined as an essential constant of the human thinking of all times and places. This constant marks the two fundamental processes of creation: "the transition from the macro-creation of the cosmic world to the micro-creation (bio-psycho-logic) of the human world; the transition from the mental creation (signification) of the world by the human to the creation (significant) created by the human society as a whole" [7, p . 
24]. Any artistic creation tends to reiterate fragmentary or quasi-integral, the making the world. In the cosmic archetype of the Creation of the World, "any construction becomes real, that is, it receives its being by fixing it to a particular place that corresponds to the Centre of the World" [4, p. 40-44].

In this symbolic area of the construction of a Centre is also the search for the place to build, an action which, in the Tradesman Manole's drama, it identifies itself with a true cosmogony, with a creation of the world that - as Eliade used to say, implicitly using the privilege of semiotics "sits for" any other creation, including human. The drama reveals a "creation about creation" suggested by the succession of the moments of construction, which implies an undulating cycle. This profound structure, suggesting "the image of the wave that is constantly born and dying, doubles that of the spiraling becoming that characterizes any processuality of the cosmic or human world" [9].

The archetypes of light equate to the exit from chaos. From a structural point of view everything that is manifestation in the architecture of the macro- or microcosmic and human (bio-psycho-logical) and cultural-technological world, presupposes the presence of four constitutive points: substance, energy, information and field. In the subsidiary of this hierarchy, the human light that is necessary for the creative manifestation of man is pulsing, which can overcome its creation, but can never overcome its creative condition. The creation is a fact of culture, but also a creative exercise. It, the Creator, has "the magical power to delimit a world, to imagine a logos, an order of it, to give it incarnation, substance and form" [10]. Every move of the human being into something else is doomed to failure; the finality will be new and new creations.

\subsection{Light, from Ontos to Logos}

In a spiritual approach, the discovery of all aspects of the Universe is essentially related to another light, the light of understanding, in the sense of knowledge by means of reason "by ecstatic contemplation, by living in mystery, deepening it"[11], which resides in the ability to convey significations and meanings.

Unlike Aristotle and Kant - who have approached the rational human dimension, in Blaga we find a set of deeper, abyssal categories that surprise the ontological basis of the human in the irrational definition of the human as a historical being in the system of the existential levels of the Universe. This involves a vertical cognitive approach that opens the perspective of the transcendent, but it is censored. In order to pass beyond immanence, the man is endowed with "spiritual gifts" mediated by "stylistic categories" that have their location in the unconscious. As bearer of stylistic categories, he/she becomes a "creative being" that strives for absolute.

Recovering an ontology of the hierarchical reality levels, Surdu [12, p.74) builds the gnoseological meanings of a "pentadic semiosis", which has as basic structure the fundamental categories of philosophy, which Lucian Blaga also follows in his own philosophical construction, grouped as follows: "Subsistence, Existence, Being, Reality, Real Existence".

Following Kant's direction on the faculties of thinking, Surdu [12, p.83-85) believes that "Where Reason fails in the field of Transcendence, Speculation succeeds, which is based on meditation and revelation. "The shift from Subsistence to Existence is part of the knowledge process. Reality, which implies the concepts about Truth, Beauty, Good, Justice, Freedom, depends on the coordinates of Existence and their possibilities of being, by their Being.

If the Scholastics described Transcendence as an "excess" of thinking that places us on the metaphysical realm, for Dionysius (Pseudo) Areopagite, Transcendence is "coincidentia oppositorum" in the sense of the over bright darkness "the brightness of the darkness" or "the darkness of light" [13]. Therefore, such combinations are not accepted from the perspective of Reason, which are based on an "absolute knowledge" equivalent to an "intellectual intuition" [12, p. 268-273], and the divine Absolute is the field of the "proper speculative thinking". After Nicolaus Cusanus, Transcendence goes beyond both senses, reason and intelligence. Therefore, the access to knowledge presupposes not the absolutisation of Intelligence/Reason, but the overcoming, transcendence through revelation, through which it becomes aware of Eternity, of Transcendence in general.

\subsubsection{Hermeneutics and the Matter of Knowledge in Blaga's Vision}

A concept with multiple connotations in Blaga's work, the light expresses first of all the idea of knowledge, that is that "logos apophantikos" (illuminating) attributed by Aristotle to the human thinking, it is the symbol of the absolute knowledge, the rest of the "original light". The whole existence is paradoxical, being a synthesis between mystery and knowledge, and it cannot be reduced to just one of the two categories because "everything cannot be reduced to knowledge or mystery. The mystery is the point of intersection of the immanent and the transcendent, ensuring the continuity between them. The penetration of the human into the mystery Universe involves a vertical cognitive approach that opens the perspective of the transcendent. Therefore, the transcendent is coexistence with the human, and the problem of participation is a problem of anthropological and not ontological competence (Heidegger). Man is not only an epistemological subject but also an axiological subject.

We do not have an exact knowledge of the creation, because of the mystery that persists in it, and even more so of the Divinity whose mystery is transcendent to us. A knowing subject, the human has the possibility of gathering the rationale of things in order to enrich himself spiritually, so he has access to a paradisiac knowledge that does not 
know mysteries. The light-filled creator replaces transcendence, in its absence it becomes a demiurgist himself of a Universe which he expresses magicopoetically. The man's paradox is that he is attracted to the meanings or reason he discovers in himself or in creation, but always remains in mystery, advancing in the mystery of an absolute world, at the end of which he can never reach.

On the ideational background of Blaga's work, which consists in the drama of the human between mystery and revelation, the creator's destiny is projected in its double condition: the human dimension, on the one hand, and on the other, the creative genius, which has the force of neutralizing the man-nature opposition. The human, as a specific way of being, is oriented towards the horizon of the mystery and endowed with the destiny of trying to reveal the mysteries. The mysteries are in an inaccessible sphere of incognostible and inexplicable, censored transcendently through a stylistic matrix whose stupid, stylistic categories are "transcendental brakes, a kind of forces imposed on man and his creative spontaneity so that he can never reveal positively the mysteries of the world"[14]. As no matter how we go towards it, the horizon of the mystery can never be fully deciphered.

Starting from the definition of knowledge in its simplicity, we delimit the idea according to which "knowledge is a necessary relation between subject and object and can only be conceived as an open act on the object"[15]. But Blaga's knowledge is detached from this definition, being an act of transcendence within certain limits: the intervention of the transcendent censorship through the action of the metaphysical, ontological centre of existence of the Great Anonymous, which limits a total and positive transcendence of the absolute. For Plato and Aristotle, knowledge is made on levels, so there is "abstract, discursive, verbal knowledge and direct-intuitive knowledge"[16]. For Kant, the laws of the human reason are a priori. He tries to render the human knowledge to his horizon dimension. Having a horizon, conceived as a condition of a "face to face" [17] of all things in their quality of object is a specific human feature knowledge.

Instead of the absent divinity, the lyrical ego replaces the creative self of another monad that is the creation, the work itself and tries to magically acquire the power to express and reveal in it the transcendent itself. The light is loaded with gnostic potentials when its meaning is to enrich the "dark horizon with great mysteries of the holy mystery" [18] because "the act of knowledge must become a function of the act of creation; in the artist he recognizes the great creator "[19]. So, "the man must be a creator, so to give up joyfully to the knowledge of the Absolute" [20], because the true enlightenment is made through the mediation of the creative love that goes beyond any intellect.

\subsubsection{Triadic-relational Analysis of the Cognitive Approach}

The Blagian concept on knowledge and the Creator's purpose expressed in poetry I do not strike the wreath of wonders of the world, at the head of the debut volume The Poems of Light express the idea of the impossibility of knowing the underlying mysteries of the world. "My Light" expresses the poet's perspective for whom the Universe is not only a cognoscible reality subject to an intellectualanalytical and positive knowledge, but a world of signs, symbols that poetry preserves. The "flowers," "eyes," "lips," "graves" are parts of a whole that the philosopher poet can perceive and rebuild magically in its totality through an act of love and poetic narration "[10, p.135]. Pop observes the preference of the Blagian poetic imagery for the curve-space represented by the cup Universe "miracle corollum" as the receptacle of the high light for the circularity of the sacred space placed in the "centre of the world" (house, circle of the same home, mythological geography) but also of the time (cyclic "round-time").

Approaching the world's mysteries by means of the light, it helps to increase them by releasing the primordial creation impulse: "I with my light increase the mysterious world." The poet knows that two lights are hiding in the light of the ego: one of the minds that kills the mysteries and strangles the spell" in an irreducible position with the" unseen hidden" in the depths of darkness and the other solitary with the mystery of the night"[21] . The self itself integrates with the Universe, to which it opens in an osmotic communion, illuminates and illuminates itself. Here we can see a relationship between the part and the whole of the form and content, between the "deep structure and the surface structure" [22]. Within the limits of this relationship the transformation of cosmic (electromagnetic) relationships can be highlighted in the process of transition from "the physical light" (natural, cosmic) to "the biological light" (bioluminescence) and then to "the spiritual light" (psychological understanding, creative mental construction).

Therefore, starting from the level of physical light, we can define three modes of being of the "light"[23]:

- The bio light (bioluminescence) specific to the biological stage of the existence (alive / human): "flowers", "eyes", "lips", "graves";

- The psycho light (psycholuminescence), characteristic of psychic activity (affective-emotional), of the human being: "I love";

- The noesi light, characterizing the emission of the "spiritual light"; generated by the mental (voltive-intellectual) activities, "but I, with my light, increase the mysterious world-/ and, as with its white rays, the moon/does not diminish, but trembling/increases the mystery of the night/so I increase the darkness/with the great flowers of the holy mystery ... ". The levels of reality: physical, biological and psychic are found in the horizon of the essential metamorphosis: light bio light-psycho light. At the intersection of these horizons the "complex light" that can be empirically highlighted is defined.

The meeting with the light ends by radically 
transforming a human existence, making it open to the world of the spirit, as Eliade states [24]: "He who experiences such experiences undergoes an ontological mutation, acquiring another way of being which gives him access to the spiritual world, it is the sign of a new spiritual birth." Although the inner light confers paragnomical skills, preparing it for a mystical knowledge, for the philosopher poet it means philosophical understanding and acceptance of the existential mystery, which also includes the ultimate reality, called by Blaga the Great Anonymous, which is often manifested by a series of bright epiphanes.

In conclusion, the light can symbolize the higher stage of knowledge because "the reporting to Existence also occurs as Transcendence and as Transcendental (from here and beyond the existence, being simultaneously one and the other)" [12, p.83-85]. The transcendence is the category of what goes beyond the other categories. In a way, through the light, the Universe comes to us, and the abysses of the matter open to investigations and interrogations of the human. The creation is made in such a way as to help us in overcoming our own limits. On the other hand, we also advance in knowledge through the powers of the reason admirably suitable to the world in which we live. The Universe opens to the human's reason through the physical world, and the human discovers it to the world according to him.

\section{The Senses of the "Living Light", the Archetype of "Becoming into Being"}

The presence at the level of every living organism (even dead) of a specific energy-information matrix surrounding it as a tire, can no longer be questioned. The essence of the light is required to be recognized by metaphysics as "the main element of the present being" [25]. In the manifestation of the "essential unity" of the world, the word light - equally physical (by its signifier) and metaphysical (by its significance) is a reference binder, $[9 \mathrm{p}$. 58]

As an energy and information source, the light plays an essential role in the organization and functioning of the living matter. Starting from the meaning of the primordial element of creation and that of the world (cosmos), understood from the Latin lumen, a suggestive relationship is created between two distinct stages of being of the light: the cosmic (natural) and the biological stage, which denotes the unity between macro- and microcosm. From the primordial ghost, the light brings life, increases the mysteries of the world, being "a drop of light/created on the first day/the light deeply thirsty for life" (Blaga, Light).

The symbol of light takes place at Blaga in the "spirit of a heractic vision, where everything is done and undone." Such a dispute between the structuring and destructuring principle is found almost as much in the literary work of the Trademan Manole, where the sacrament of the construction will be done through an essential germ: life itself. The absence of this element as a structural binder determines the imperfection of construction by the inability of its builders to detach it from chaos. The sequence of days and nights, of light and of darkness has a symbolic value: the presence of darkness as a factor with destructive effects on the creation provokes a permanent return from the orderly (cosmic) to the disorganized (chaotic) stage.We speak in this context of the symbolism of universal circulation. The build-in woman will offer the living binder (ontos) that will make the monastery last. In this sense, the built-in woman becomes a symbol of the vital transfer that ensures the construction durability. Perceived as "the last drop/from the light created on the first day", because it is magical and sacred, the light repeats itself as the moment of genesis. A magic circuit unites the elements of the cosmos, of the tellurium with the human being.

Replacing the beloved woman with the worship place gives the social time the meaning of cosmic eternity in a vision that absolutises the relative of life. Manole is the type of absolute artist, "he is firmly convinced that the great masterpieces involve the sacrifice of lives" [26]. The woman's role stops here: it remains ritual and sacrificial. Her sacrifice is all the more upsetting as she had never agreed with her. "Wonderful wonder before the enigmas, the urge aspiration to the light, the acceptance of the game of the building with a sublime innocence (...) gives the last scene where Mira appears a special tragism. The character seems to descend from the Paradise areas into an abyss which he does not understand, but purifies him by his mere presence "[27]. The icon of the worshiped being is seen as an archetype, which is why her underestimation, but only the generalizing appointment "My beautiful ... my light". Because "there is in us something deeper than ourselves that Augustine translated into transcendental, in the opening of the self" [28], the philosopher "remains in constant search for light as a sign of the divine or of the potential maximal creator "[29] "I'm looking, I do not know what I'm looking for. Under the stars yesterday, / under the past, I'm looking / the extinguished light that I still praise" (The Light of yesterday).

The cosmos and human are seen as realities, as paradoxical unity of light and mystery. The human is in a higher degree, both light, meaning reasoning and mysterious reason, referring here to the insubstantial depth of the person. The hideout of the human being originates in the "hiding" of the divine being; the human's mystery is in his divine model in the Archetype [30]. In other words, man is the key to the world through which the whole life is revealed. Even the term "existence" betrays the latent epistemological immanence as a spring of existentialism [31]. The light belongs to a semantic sphere in which the fire, the sun, the moon, the stars, the symbols that concentrate close senses, irrading in different degrees an aura of light and, implicitly, of poetic meanings are integrated. In the mystical physiology techniques, "the 
unification of the two sacred, cosmic energy centres, namely the moon and the sun, aim at their reintegration into the primordial Unity, undifferentiated and still unfragmented by the act of cosmic creation, which translates into a transcendence of the Cosmos" [24, p.149].

Among the uranium elements, generating light and heat (the stars, the moon, the sun), the stars are the sign of the cosmic integrative vision of the world, through which the philosopher poet establishes a way of understanding the ego - universe. The symbol of light "isotropic field inducer" unites the extremes fixed by the two axes of the paradigm and syntagm. Due to their horizontal movement, the stars remain at the same level - the celestial -, at a great distance from the human, therefore they will no longer be but an aspiration. The flow of the stars to the earth creates to the human the illusion of the fusion with the cosmic: "Stars flowing/washing our earth" (Extatic Night) Their light "spiritualizes the light in human" [29, p.88] by a constant downward movement between Heaven and Earth.

Where we deduce the idea that the human knowledge is limited to the perception of the external, of the appearance, it cannot contain the essence, being limited. "The star is a messenger or part of the absolute "divine differential"; the human being is not able to embrace it in its essence, but only to accept it in its appearance as "brightness" "[32]. In this sense, we can see two directions: one from the concrete to the abstract - the paradigmatic axis and the other from the abstract to the concrete - the syntagmatic axis. But beyond the fixed star vault it is "the seat of the Divine Intelligence, of pure, immaterial Form. In this cosmological-theological picture, the spatial, physical, astronomical sense of the idea of transcendence is clearly expressed "[31, p.286].

\section{Conclusions}

As a conclusion, if the birth of the world, according to the principle of creation, involves the exit of the Light (cosmos-order) from the Darkness (the chaos of disorder), that is, the fundamental forms of nature are generated by the energy-information fields of the "complex light" [6, p.64,90]. We can say that the light is responsible for the genesis of the forms and their fundamental functions in the world. And the human, foreseeing the transcendent, aspires to a transition to transcendent because, based on this aspiration; he circumscribes (see Heidegger and Noica) the horizon of his specific human condition.

With some semiotic landmarks in approaching the theme of the light in Blaga's work, we can deduce some force-ideas on which the present paper is built. The central idea around which the work is confronted refers to three ways of being of the light: bio light, psycho light, noesi light; at the intersection of these horizons defining the complex light. Structured in two chapters: The hypostasis of Blaga's light in the horizon of the semiotic analysis and The meanings of the "living light", the archetype of becoming "in being", the work is required by the complementary approach of the semiotic analysis: the triadic-relational cognitive approach, in the first chapter and the interpretation of hermeneutics of the light in the next chapter. Thus, the structure of the work is a way of accessing Blaga's sense-world and identifying the specificity of the light in Blaga's creation. The semiotic approach takes place through an implicit overlap of the semantic field that calls the light term with its hermeneutical interpretation.

In the chapter The Hypostases of the Light in the Horizon of Semiotic Analysis, we have referred to the cosmogonic and demiurgic functions of the light, ontologically valorizing the mysterious Universe in front of which the human being finds tension between the consciousness of the limits and the aspiration to overcome them. The transcendent is the coexistence of the human, from where the human's desire to penetrate into the world of mysteries through a cognitive approach. Regarding the gnoseological function of the light, we have revealed the distinction between the Paradise knowledge and the Lucifer knowledge, emphasizing the importance of the latter for the human being. The Lucifer knowledge, unlike the Paradise knowledge, does not break the complexes of phenomena into concepts, but transforms them into a "complex of signs of a mystery"[33]. A knowing subject, the human has the possibility of gathering the rationality of things, so he has access to a paradisiac knowledge that does not know mysteries. The poet illuminated by the light replaces the transcendence, in its absence he becomes a demiurg himself of a Universe he expresses magico-poetically.

In the Section "Senses of the Living Light", an archetype of becoming "in being", the light - both a carrier of information and energy - is a common paradigm for unifying the two axes: paradigmatic and syntagmatic, starting from the hypothesis of the metamorphosis of "uncreated light and/or created "in the "spiritual light "of the human language (the creator) that is no longer a metaphor without a native foundation. At the interference of the two axes we encounter the erotic connotation of the light, which is burning and consuming passion in the human being for the realization of the creation. It can only be through the eternity of life. Generally speaking, the Light is perceived as the centre of the creation Universe, which gives it coherence and meaning. In Blaga's conception, the artwork is cosmoid, a new Universe that must have a generating light-bearing principle, and this is the human subject that seeks its place in the still unknown space.

\section{REFERENCES}

[1] Chevalier, J. \& Gheerbrant, A., Dicționar de simboluri, București: Artemis, 1995, p. 205. 
[2] Moretta, A., Mituri antice și mitul progresului, București: Ed. Tehnică, 1994, p.195.

[3] Mihalache, A. S., Lumina celui Nevăzut, București: Basilica, 2016, p.379.

[4] Fanache, V., Chipurile tăcute ale veșniciei în lirica lui Blaga, Cluj-Napoca: Ed. Dacia, 2003, p.40-44.

[5] Câlugea, Z., Lucian Blaga. Universul clepsidră și matricea stilistică, Iași: Princeps Edit, 2013, p.43.

[6] Poenaru, A., Arhitectura luminii (Inițiere în semiotica formelor sacre), Iași: Performntica, 2013, p.41.

[7] Stănciulescu,T. D., (Meta)fizica Luminii, Iași: Performantica\&Biophotonic-Concept, 2017, p.18.

[8] Eliade, M., Traité d'histoire des religions, Paris: Payot, 1968, 345.

[9] Stănciulescu, T. D., Tratat de creatologie, Iași: Performantica, 1998, p.31-32.

[10] Gavrilă, C., Mitic şi magic în opera lui Lucian Blaga, Iaşi: Ed. Junimea, 2002, p.14.

[11] Zissu, M., Dicționarul limbii poetice a lui L.Blaga, Constanța: Eurolopis, 2004, p.269.

[12] Surdu, Al., Introducere în Filosofia pentadică, București: Herald, 2012, p.74.

[13] Areopagitul, D (Pseudo) Despre numele divine, Sibiu: Deisis, 1997, p. 148-149.

[14] Blaga, L., Trilogia Culturii, București: Minerva, 1969, p.371.

[15] Tănase, Al., Studiu introductiv în Trilogia Cunoașterii, Opere 8, București: Minerva, 1983, p.31.

[16] Berceanu, Șt. \& Anton, D., Cartea interferențelor, București: Ed. Științifică și Enciclopedică, 1985, p.99.

[17] Beaufret, J., Lecții de filozofie. De la Platon la Heidegger. Vol. II, Timişoara: Armarcord, 1999, p.83.

[18] Blaga, L., Opere I, Poezii, Bucureşti: Minerva, 1974, p.80.

[19] Gorgoi, L., Friedrich Nietzsche și cultura românointerbelică, Cluj: Casa Cărții de Știință, 2000, p.18.

[20] Blaga, L., Opere, vol.7, București: Minerva, 1982, p.81.

[21] Pop, I., Universul liric, Iaşi: Colecția Deschideri, seria Universitas, 1999, p.6.

[22] Bergson, H., Eseu asupra datelor imediate ale conștiinței, Iași: Institutului European, 1998, p.95.

[23] Isac, V., \&Stănciulescu, T.D., Fundamentele valorii, Iași: Performantica, 2006, p.229-230.

[24] Eliade, M., Mefistofel și androginul, București: Humanitas, 1995, p.30.

[25] Mureșan, V., Fundamentele filosofice ale magiei, Cluj Napoca: Dacia, 2000, p.83.

[26] Gană, G., Opera literară a lui Lucian Blaga, București: Ed. Minerva, 1976, p.233.
[27] Ciompec, Gh., Motivul creației în literatura română, București: Minerva, 1979, p.136.

[28] Liiceanu, G., Jurnalul de la Păltiniș.Un model paideic în cultura umanistă, București: Humanitas, 2005, p.92.

[29] Solomon, L., Poetica elementelor în lirica lui Lucian Blaga, Iaşi: Institutul European, 2008, p.82.

[30] Popescu, D., Ortodoxie și contemporaneitate, București: Sophia, 1996, p.62.

[31] Florian, M., Recesivitatea ca structură a lumii, vol.I, Bucureşti: Eminescu.1983, p.288.

[32] Indrieș, Al., Sporind a lumii taină. Verbul în poezia lui Lucian Blaga, București: Minerva, 1981, p.217.

[33] Blaga, L., Trilogia Valorilor II (Gândire magică şi religie), București: Humanitas, 1996, p.130. 